\title{
Correction to: 4R-cembranoid confers neuroprotection against LPS-induced hippocampal inflammation in mice
}

Luis A. Rojas-Colón ${ }^{1}$, Pramod K. Dash, Fabiola A. Morales-Vías' ${ }^{1}$, Madeline Lebrón-Dávila ${ }^{1}$ Pedro A. Ferchmin ${ }^{1}$, John B. Redell2 ${ }^{2}$ Geronimo Maldonado-Martínez ${ }^{3}$ and Wanda I. Vélez-Torres ${ }^{{ }^{*}}$

\section{Correction to: J Neuroinflammation 18, 95 (2021)}

https://doi.org/10.1186/s12974-021-02136-9

Following publication of the original article [1], the authors noticed that the image of the diagram model in the conclusion section was missing. Presented here is the correct image. The original article has been corrected.

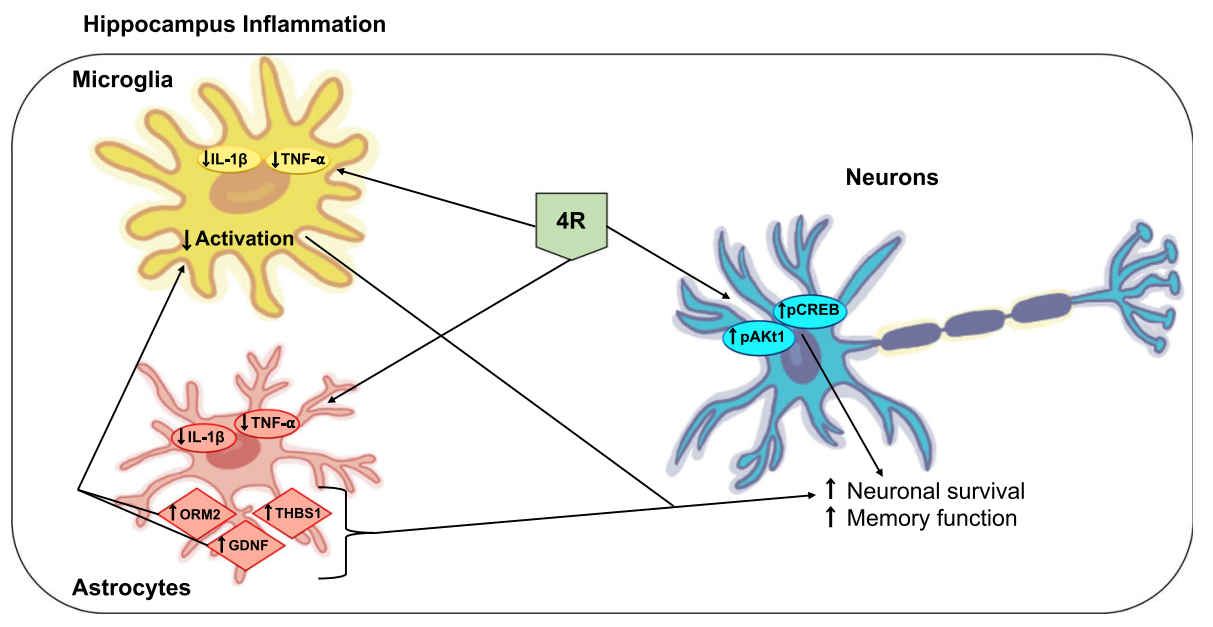

The original article can be found online at https://doi.org/10.1186/s12974021-02136-9.

* Correspondence: wanda.velez@uccaribe.edu

${ }^{1}$ Department of Biochemistry, Universidad Central del Caribe School of Medicine, Av. Sta. Juanita, Bayamón 00960, Puerto Rico

Full list of author information is available at the end of the article

\section{Author details}

${ }^{1}$ Department of Biochemistry, Universidad Central del Caribe School of Medicine, Av. Sta. Juanita, Bayamón 00960, Puerto Rico. Department of Neurobiology and Anatomy, McGovern Medical School, University of Texas Health Science Center at Houston, Houston, TX 77030, USA. ${ }^{3}$ University of Puerto Rico Molecular Science Research Center, Av. Juan Ponce de León, San Published online: 26 May 2021

\section{Reference}

1. Rojas-Colón LA, Dash PK, Morales-Vías FA, Lebrón-Dávila M, Ferchmin PA, Redell JB, et al. 4R-cembranoid confers neuroprotection against LPSinduced hippocampal inflammation in mice. J Neuroinflammation. 2021; 18(1):95. https://doi.org/10.1186/s12974-021-02136-9.

(c) The Author(s). 2021 Open Access This article is licensed under a Creative Commons Attribution 4.0 International License, which permits use, sharing, adaptation, distribution and reproduction in any medium or format, as long as you give appropriate credit to the original author(s) and the source, provide a link to the Creative Commons licence, and indicate if changes were made. The images or other third party material in this article are included in the article's Creative Commons licence, unless indicated otherwise in a credit line to the material. If material is not included in the article's Creative Commons licence and your intended use is not permitted by statutory regulation or exceeds the permitted use, you will need to obtain permission directly from the copyright holder. To view a copy of this licence, visit http://creativecommons.org/licenses/by/4.0/ The Creative Commons Public Domain Dedication waiver (http://creativecommons.org/publicdomain/zero/1.0/) applies to the data made available in this article, unless otherwise stated in a credit line to the data. 